http://jmscr.igmpublication.org/home/ ISSN (e)-2347-176x ISSN (p) 2455-0450 crossref DOI: https://dx.doi.org/10.18535/jmscr/v7i8.125

Journal Of Medical Science And Clinical Research

\title{
USG Guided FNAC (Fine Needle Aspiration Cytology) is highly Sensitive and Specific Procedure for the Diagnosis of Lung Tumors, in Tertiary Care Hospital, at Muzaffarpur, Bihar
}

\author{
Authors \\ Dr Vimal Kumar Gupta ${ }^{1}$, Dr Awadhesh Kumar Singh ${ }^{2 *}$, Dr Manoj Kumar ${ }^{3}$ \\ ${ }^{1}$ Assistant Professor, Department of Pathology, S. K. Medical College, Muzaffarpur \\ ${ }^{2}$ Assistant Professor, Department of Pathology, S. K. Medical College, Muzaffarpur \\ ${ }^{3}$ Professor and HOD, Department of Pathology, S. K. Medical College, Muzaffarpur \\ *Corresponding Author \\ Dr Awadhesh Kumar Singh \\ Assistant Professor, Department of Pathology, S.K. Medical College, Muzaffarpur, India
}

\begin{abstract}
Objective: The aim of present study was to determine the role of fine needle aspiration cytology (FNAC) in diagnosis of Lungs tumor and its diagnostic accuracy as well as evaluate the incidence and prevalence of lung cancer in various age and sex group and in relation with smoking.

Materials and Method: A total of 72 patients Referred to our department for USG guided FNAC with suspected Lung mass lesion admitted through medical, surgical OPD and emergency. After detailed medical and surgical history, clinical examination was done, Routine investigations $(C B C, B T, C T, P T$ and aPTT) were done before the procedure. Recent Plain and contrast CT of chest made available prior to USG guided FNAC. Written consent was taken from each patient. FNAC was done and five to seven smears were prepared, fixed and stained with May-Grunewald Giemsa stain/papanicolaou, and H\&E stain.

Results: Out of 72 patients, 64 patients $(88.89 \%)$ were male and $8(11.11 \%)$ patients were female. Male to female ratio was 8:1. The age of patients varies from 25-75 years most of the patient was in the age group of 50-70 years. The most common tumor was squamous cell carcinoma in 33(45.83\%) patients followed by adenocarcinoma in 16 patients $(22.22 \%)$, small cell carcinoma in 13 patients $(18.05 \%)$ and large cell carcinoma in 5 patients (6.94\%). 57 patients (79.16\%) out of 72 patients had history of smoking.

Conclusion: USG Guided Fine Needle Aspiration cytology is a simple, safe, highly sensitive and specific procedure with high diagnostic accuracy for diagnosis of Lungs mass lesions. Diagnostic accuracy of cytology with final histopathological report was established with accuracy rate of $94.44 \%$.

Keywords: Fine needle aspiration cytology, Lung tumor, diagnostic accuracy.
\end{abstract}

\section{Introduction}

Fine needle aspiration cytology (FNAC) is a well established technique for the diagnosis of lung tumors. Leyden in 1883 and Menebriel in 1986 introduced the technique and diagnostic lung puncture for identification of microbes and malignant cells. Opacity in the lung is many a times puzzle to the clinicians, the conventional diagnostic procedures like $\mathrm{X}$ ray chest, complete sputum examinations, bronchoscopy and others may remain inconclusive in number of cases. So for the therapeutic evaluation, histopathologic 
procedure is mandatory in every case. Although thoracotomy is the most accurate diagnostic procedure to determine the etiology of pulmonary lesion, it is costly, risky, requires general anesthesia as well as surgeons help. So one of the alternatives is a percutaneous fine needle aspiration from suspected lung lesion.

This study was done to assess the usefulness of FNAC as a diagnostic method in lung tumor as well as to determine the incidence of lung cancer in various age and sex groups and in relation to smoking.

\section{Materials and Methods}

Present study was conducted in the Department of Pathology, Sri Krishna Medical College, Muzaffarpur, Bihar, with the help of Department of Medicine, Surgery, and Pediatrics during the period of July 2017 to January 2019.

A total of 72 patients Referred to our department for USG guided FNAC with suspected Lung mass lesion admitted through medical, surgical OPD and emergency. After detailed medical and surgical history, clinical examination was done, Routine investigations (CBC, BT, CT, PT and aPTT) were done before the procedure. Recent Plain and contrast CT of chest made available prior to USG guided FNAC. Written consent was taken from each patient. FNAC was done by 21 22 gauge needles under guidance of ultrasonography and five to seven smears were prepared, fixed by placing them immediately into coplin jars containing 95\% ethyl alcohol and stained with May-Grunewald Giemsa stain/ papanicolaou, and H\&E stain.

Paraffin section was prepared on the remaining tissue sample. Material collected for cytological and histological examination was analyzed. FNAC diagnosis was correlated with paraffin section reports.

\section{Result}

Out of 72 patients, 64 patients $(88.89 \%)$ were male and $8(11.11 \%)$ patients were female. Male to female ratio was $8: 1$. The age of patients varies from 25-75 years most of the patient was in the age group of 50-70 years. The most common tumor was squamous cell carcinoma in 33 patients (45.83\%) followed by adenocarcinoma in 16 patients $(22.22 \%)$, small cell carcinoma in 13 patients $(18.05 \%)$ and large cell carcinoma in 5 patients (6.94\%). Out of 72 patients, 57 (79.16\%) patients had history of smoking. 31 out of 33 patients of squamous cell carcinoma and 12 out of 13 patients of small cell carcinoma were smokers. Among 16 patients of adenocarcinoma only 6 patients were smokers, so history of chronic smoking is more commonly seen in patients of squamous cell carcinoma and small cell carcinoma.

Out of 72 patients, in 68 patients FNAC diagnosis was confirmed by histopathological diagnosis. So over all diagnostic accuracy of our study was $94.44 \%$.

In 04 cases histological diagnosis was not matched by cytological diagnosis. Among 04 cases 01 case of small cell carcinoma diagnosed by histopathology was reported as adenocarcinoma by FNAC and 01 cases of squamous cell carcinoma were diagnosed as adenosquamous carcinoma by FNAC. 01 of adenosquamous carcinoma and 01 of poorly differentiated carcinoma reported by FNAC were correctly diagnosed as adenocarcinoma and large cell carcinoma on histopathology respectively (Table 4).

Table- 1 shows Age distribution of patients.

\begin{tabular}{|l|c|c|}
\hline $\begin{array}{l}\text { Age of Patients } \\
\text { in years }\end{array}$ & $\begin{array}{c}\text { Total No. of } \\
\text { patients } \\
\mathrm{N}=72\end{array}$ & Percentage \\
\hline $21-30$ & 1 & 1.38 \\
\hline $31-40$ & 5 & 6.94 \\
\hline $41-50$ & 10 & 13.88 \\
\hline $51-60$ & 30 & 41.66 \\
\hline $61-70$ & 22 & 30.55 \\
\hline More than 71 & 4 & 5.55 \\
\hline
\end{tabular}

Table- 2 shows Sex distribution of patients.

\begin{tabular}{|l|c|c|}
\hline $\begin{array}{l}\text { Sex distribution } \\
\text { of patients }\end{array}$ & $\begin{array}{c}\text { Total No. of patients } \\
\text { N=72 }\end{array}$ & Percentage \\
\hline Male & 64 & 88.89 \\
\hline Female & 8 & 11.11 \\
\hline Total & 72 & 100 \\
\hline
\end{tabular}


Table- 3 Shows Types of lesion versus History of smoking

\begin{tabular}{|l|c|c|}
\hline Types of lesion & $\begin{array}{c}\text { Total no of cases } \\
\mathrm{N}=72\end{array}$ & $\begin{array}{c}\text { History of } \\
\text { smoking }\end{array}$ \\
\hline Small cell carcinoma & $13(18.05 \%)$ & 12 \\
\hline Adenocarcinoma & $16(22.22 \%)$ & 6 \\
\hline Squamous cell carcinoma & $33(45.83 \%)$ & 31 \\
\hline Adenosquaemous cell carcinoma & $3(4.16 \%)$ & 2 \\
\hline Large cell carcinoma & $5(6.94 \%)$ & 4 \\
\hline Poorly differentiated carcinoma & $2(2.77 \%)$ & 2 \\
\hline Total & 72 & 57 \\
& & $(79.16 \%)$ \\
\hline
\end{tabular}

Table 4 shows Diagnostic accuracy (Histopathological diagnosis versus Cytological diagnosis)

\begin{tabular}{|l|c|c|c|}
\hline $\begin{array}{l}\text { Histopathological } \\
\text { diagnosis }\end{array}$ & $\begin{array}{c}\text { FNAC } \\
\text { diagnosis }\end{array}$ & $\begin{array}{c}\text { Total no. of } \\
\text { Patients }\end{array}$ & $\begin{array}{c}\text { Percentag } \\
\text { e }\end{array}$ \\
\hline Confirmed & 68 & 68 & 94.44 \\
\hline Non-Confirmed & 4 & 4 & 5.55 \\
\hline Total patients & 72 & 72 & 100 \\
\hline
\end{tabular}

Table- 5 Shows Comparision between Histopathologic Diagnosis and FNAC Diagnosis

\begin{tabular}{|l|c|c|c|c|c|c|}
\hline $\begin{array}{l}\text { Histopathological } \\
\text { diagnosis } \\
(\mathrm{N}=72)\end{array}$ & $\begin{array}{c}\text { Small cell } \\
\text { carcinoma }\end{array}$ & Adenocarcinoma & $\begin{array}{c}\text { Squamous } \\
\text { cell } \\
\text { carcinoma }\end{array}$ & $\begin{array}{c}\text { Large cell } \\
\text { carcinoma }\end{array}$ & $\begin{array}{c}\text { Poorly } \\
\text { differentiated } \\
\text { carcinoma }\end{array}$ & $\begin{array}{c}\text { Adenosquaemous } \\
\text { cell carcinoma }\end{array}$ \\
\hline $\begin{array}{l}\text { Small cell carcinoma } \\
(\mathrm{N}=13)\end{array}$ & 12 & 1 & & & & \\
\hline $\begin{array}{l}\text { Adenocarcinoma } \\
(\mathrm{N}=16)\end{array}$ & 15 & & & & & \\
\hline $\begin{array}{l}\text { Squamous cell } \\
\text { carcinoma(N=33) }\end{array}$ & & & 31 & & & \\
\hline $\begin{array}{l}\text { Large } \\
\text { carcinoma(N=5) }\end{array}$ & & & & & \\
\hline $\begin{array}{l}\text { Poorly } \\
\text { differentiated(N=2) } \\
\text { carcinoma }\end{array}$ & & & & & 2 \\
\hline $\begin{array}{l}\text { Adenosquaemous cell } \\
\text { carcinoma(N=3) }\end{array}$ & & & & & & \\
\hline
\end{tabular}

\section{Discussion}

FNAC is a sensitive method for lung cancer diagnosis. 72 patients of lung cancer were seen during the study period. Peak age incidence in our patients was 51-60 years, which is similar to that observed in other studies. However peak age incidence in our study is higher than Zavala et al series. This can be due to selection of patients, it is also evident that no age was considered as contraindication for lung biopsy.

In present study male to female ratio was 8:1 which is likely to similar to other studies. The male predominance is due to greater incidence of pulmonary disease in males because smoking habits and occupational hazards are more prevalent in males. In our study $57(79.16 \%$ ) out of 72 patients had history of smoking.

In the present study accuracy of FNAC is $94.44 \%$ where as the diagnostic accuracy of FNAC of lung tumors range from 82.4 to $90.3 \%$ in previous studies. Table- 6 shows over all diagnostic accuracy and reliability of aspiration cytology in comparison to Histopathology were studied by different authors, so results of our study were consistent with other studies done in different parts of world.

Table- 6 Shows Comparative studies done by various Authors

\begin{tabular}{|l|c|c|}
\hline Name of Author & No. of Cases & $\begin{array}{c}\text { Diagnostic } \\
\text { Accuracy }\end{array}$ \\
\hline Dick et al 1974 & 227 & $78 \%$ \\
\hline Sergent et al 1976 & 350 & $83 \%$ \\
\hline Lalli et al 1978 & 1223 & $85 \%$ \\
\hline $\begin{array}{l}\text { Flower and verney } \\
1979\end{array}$ & 287 & $87 \%$ \\
\hline Khouri et al 1985 & 650 & $94 \%$ \\
\hline Calhoun et al 1986 & 397 & $92 \%$ \\
\hline Santaigo et al 1986 & 232 & $81 \%$ \\
\hline Phillips et al 1989 & 221 & $82 \%$ \\
\hline $\begin{array}{l}\text { Mondol and } \\
\text { pradhan1991 }\end{array}$ & 135 & $97 \%$ \\
\hline Present study & $\mathbf{6 8 / 7 2}$ & $\mathbf{9 4 . 4 4 \%}$ \\
\hline
\end{tabular}




\section{Conclusion}

FNAC is sensitive method for diagnosis of lung tumors, it is easy to perform, relatively safe and reliable technique. FNAC is highly cost effective and accurate as a first line investigative technique for differential diagnosis of reactive hyperplasia, inflammatory conditions, granulomatous disorders, malignancy and in stratifying cases requiring further investigations, surgical intervention and clinical follow up. The procedure is all the more valuable in resource poor economics like ours, because of its simplicity, low cost of operation and early availability of results.

\section{References}

1. Horder $\mathrm{T}$ J. Lung puncture, a new application of clinical pathology.Lancet; 2:1345-48.

2. Churchill E D Scanen R H JG, Wilkins E W.Further studies in the surgical management of carcinoma of lung. I Thoracic Surgery; 36:301-8.

3. Terada $Y$, Mutsunobe 5, Nemoto $T$ et al. Feasibility of intraoperative cytodiagnosis of lung cancer.Chest1990; 98: 1156-58.

4. Larscheid RC, Thorpe PE, Scott WJ. Percutaneous transthoracic needle aspiration biopsy. Chest1998; 114:704-9.

5. Salazer AM, Westcott JL. The role of transthoracic needle biopsy for the diagnosis and staging of lung cancer. Clin Chest Med1993; 14:99-110.

6. Gera ML et al. Role of pulmonary needle biopsy in diagnosis of pulmonary lesions.Indian J Chest Dis Allied Sci1983; 26; 109.

7. Chaudhary R et al. Percutaneous needle biopsy of lung. Indian J Chest Dis Allied Sei 1976; 18;245-50.

8. Zavala D C. The diagnosis of pulmonary diseases by non thoracotomy techniques. Chest 1973; 64:100. 58 Indian J Pathol Microbiol 2007, Vol 50, No. 1

9. Sterett G Whitakar D, Shilken KB and Walteu MN the fine needle aspiration cytology of mediastinal lesion. Cancer $1983 ; 51 ; 129-135$

10. Weisbrod GL, Lyons DJ, Tao LC ,Chamberlain W. Percutaneous fine needle aspiration biopsy of mediastinal lesions.Am J Radio11984; 525-29.

11. Dick R, Heard BE, Hinson KFW, Kerr TH ,Pearson MC. Aspiration needle biopsy of thoracic lesions, an assessment of 227 biopsies.Br I Dis Chest1974; 68:86-94.

12. Sergent EN, Turner AF, Gordonson J, Schwinn CP ,Pashky 0. Percutaneous pulmonary needle biopsy: report of 350 patients. Am J Roentgenal1976; 122:95868.

13. Lalii AF, Mc Cormack LJ, Zelch, M, Reich NE ,Belovich D. Aspiration biopsy of chest lesions. Radiology1978; 127:3540.

14. Flower CDR ,Verney GT.Percutaneous needle biopsy of thoracic lesions. An evaluation of 300 biopsies Clin Radiol 1979; 30:215-18.

15. Khouri NF, Stitik FP, Ezozan YS et al.Transthoracic needle aspiration biopsy of benign and malignant lung lesions. AIR 1985; 144:281-88.

16. Santaigo SM, Lehrman S and Williams AJ.Aspiration of lung biopsy with ultra thin needles. Respiration 1986; 50:97-101.

17. Calhoun P, Feldman PS, Amstrong P. The clinical outcome of needle aspiration of lung when cancer is not diagnosed. Ann Thorac Surg 1986; 41:592-96.

18. Phillips J, Goodman B , Kelly V. Percutaneous thoracic aspiration needle biopsies. Pathology1982; 14:211-13.

19. Mondal, Pradhan. Role of Percutaneous Fine Needle Aspiration Cytology (FNAC) in Detection Of Lung, Pleural and Mediastinal Tumours- A Study Of 162 cases. IJPM 1991; 34(4):253-58. 